\title{
Production Potential of Maize (Zea mays L.)- Based Intercropping Systems under Foothill Condition of Nagaland
}

\author{
Lowrence Kithan and L. Tongpang Longkumer
}

Dept. of Agronomy School of Agricultural Sciences and Rural Development Nagaland University, Medziphema Campus, Nagaland (797 106), India

\section{Corresponding Author}

Lowrence Kithan

e-mail: lowrencekithan@gmail.com

\author{
Article History \\ Article ID: AR1846 \\ Received in $8^{\text {th }}$ September, 2017 \\ Received in revised form $24^{\text {th }}$ September, 2017 \\ Accepted in final form $4^{\text {th }}$ October, 2017
}

\begin{abstract}
A study was conducted on Production potential of Maize (Zea mays L.)- Based Intercropping systems at the experimental farm of School of Agricultural Sciences and Rural Development (SASRD) Nagaland University, Medziphema Campus, under rainfed condition during 2015 and 2016. The treatments comprised of different row ratios i.e. (1:1), (1:2), (2:1) and (2:2) respectively of maize intercropped with perilla, sesame, ricebean and soybean. The experiment was laid in RBD with 3 replications and 21 treatments. Sole maize recorded the best with regard to growth parameters like plant height, leaf area plant ${ }^{-1}$ and stem thickness with its pooled at $315.25 \mathrm{~cm}, 2.23 \mathrm{and} 2.44 \mathrm{~cm}$. While in regard to yield parameters sole maize recorded superior than all other sole crops with its pooled in respect to number of cobs plant ${ }^{-1}$ (1.92), cob weight (g) (144.17 g), number of grains cob-1 $(555.67)$, shelling percentage (80.83), grain yield (4280.06 kg ha-1) and stover yield $\left(5296.82 \mathrm{~kg} \mathrm{ha}^{-1}\right)$. Among the different intercropping systems paired rows (2:2) ratios of maize+soybean performed significantly better in terms of yield with pooled of $\left(1565.65 \mathrm{~kg} \mathrm{ha}^{-1}\right)$ and production efficiencies viz., LER $(1.78,1.78), \operatorname{RCC}(53.95,55.22)$, CEY (4692.63 kg ha-1, $\left.4701.3 \mathrm{~kg} \mathrm{ha}^{-1}\right)$, ATER $(1.53,1.53)$, Aggressivity $(0.04,0.041)$ and SPI $(75.36,77.20)$. As for economics, paired rows $(2: 2)$ ratios of maize+ soybean proved superior to all other treatments in net return ( $₹ 1,42,612.6$, ₹ $1,44,779.4)$, gross return $(₹ 1,72,612.6$, $₹ 1,74,779.4)$ and B:C ratio (4.75 and 4.82$)$.
\end{abstract}

Keywords: Maize, perilla, sesame, ricebean, soybean, production efficiencies, economics

\section{Introduction}

The greatest challenge of $21^{\text {st }}$ century in many developing countries is to meet the ever increasing demand for basic necessities namely food, fibre and fuel for human consumption and fodder for rearing domestic animals from the limited available land. Nearly $90 \%$ of food requirements will be met from land based farming systems. The availability of land for agriculture is shrinking day by day as it is being utilized for many non agricultural purposes. Intercropping has been recognized as a beneficial system of crop production. Most common advantage of intercropping is the production of greater yield on a given piece of land by making more efficient use of the available growth resources using a mixture of crops of different rooting ability, canopy structure, height and nutrient requirements based on the complementary utilization of growth resources by the component crops. Maize (Zea mays L.) is one of the important cereal crops next to wheat and rice in the world and maize-pulse cropping system is most important food legume based system in the country. Maize or corn is the third most important crop in
India after rice and wheat grown over 8.67 mha with 22.26 $\mathrm{mt}$ production having an average productivity of $2566 \mathrm{~kg}$ ha 1 , contributing $8 \%$ in national food basket (DACNET, 2014). The area, production and productivity of maize for the year 2012-2013 under Nagaland was 63530 ha, 124580 metric tonnes and $1960 \mathrm{~kg} \mathrm{ha}^{-1}$ (Kharif) and $5140 \mathrm{ha}, 10070 \mathrm{mt}$ and $1960 \mathrm{~kg} \mathrm{ha}^{-1}$ (Rabi) (Anonymous, 2014). Perilla frutescens (L.) Britt. belonging to the family Lamiaceae (Labiatae) is native to mountainous areas of China and India and is grown mainly in Asia. In northern India the stem of the plant is traditionally used as an analgesic and anti-abortive agent.

Sesame or gingelly (Sesamum indicum L.) commonly known as til (hindi) is an ancient oilseed crop grown in India and perhaps the oldest oilseed crop in the world. It is one of the important edible oilseeds cultivated in India. The area, production and productivity of sesamum for the year 20122013 under Nagaland was 3540 ha, $2130 \mathrm{mt}$ and $601 \mathrm{~kg} \mathrm{ha}^{-1}$ (Kharif) (Anonymous, 2014). Ricebean (Vignaumbellata) a new introduction in the country, is a versatile crop. It is a good food grain, a fodder, and a cover crop. However, its economic utility 
and complete production technology is yet to be determined (Ahmed \& Ashiq, 1992). The area, production and productivity of ricebean for the year 2012-2013 under Nagaland was 4630 ha, 5060 metric tonnes and $1092 \mathrm{~kg} \mathrm{ha}^{-1}$ (Kharif) (Anonymous, 2014). Soybean (Glycine max (L.) Merrill) is an important and a major oilseed crop of the world. In Nagaland, The area, production and productivity of soybean for the year 20122013 under Nagaland was 24.67 thousand ha, $30880 \mathrm{mt}$ and $1251 \mathrm{~kg} \mathrm{ha}^{-1}$ (Kharif) (Anonymous, 2014). It is one of the most popular food items of majority of the people of Nagaland and is utilized as a pulse crop and as fermented products locally called as 'Akhuni'.

\section{Materials and Methods}

The field experiment was conducted at the experimental farm of School of Agricultural Sciences and Rural Department, Department of Agronomy, Medziphema Campus during the Kharif of 2015 and 2016 under rainfed condition. The experimental site is located at $25^{\circ} 45^{\prime} 43^{\prime \prime}$ North latitude and $93^{\circ} 53^{\prime} 04^{\prime \prime}$ East longitude at an altitude of 310 meter above mean sea level. The climate of the experimental farm represents sub-humid tropical climate zone with relative humidity, moderate temperature with medium to high rainfall. The mean temperature ranges from $21^{\circ} \mathrm{C}$ to $32^{\circ} \mathrm{C}$ during summer and rarely goes below $8^{\circ} \mathrm{C}$ in winter due to high atmospheric humidity. The average rainfall varies between 2000-2500 mm starting from April and ends with the month of September while the period from October to March remains complete dry. The soil of the experimental plot was categorized as sandy loam and well drained. To ascertain the fertility status, soil samples from a depth of $0-20 \mathrm{~cm}$ were collected at random using soil auger before starting the experiment for their mechanical and chemical analysis. The experiment was conducted in randomised block design with 3 Replications and 21 Treatments. The treatments comprised of sole crops of maize, perilla, sesame, ricebean and soybean with different intercropping treatments of 1:1, 1:2, 2:1 and 2:2 respectively (Table 1 ). The initial nutrient status of the field for Organic carbon, Available N, P and K was 1.65, $210 \mathrm{~kg} \mathrm{ha}^{-1}$, $18.5 \mathrm{~kg} \mathrm{ha}^{-1}$ and $202.45 \mathrm{~kg} \mathrm{ha}^{-1}$.

\section{Results and Discussion}

\subsection{Growth parameters}

1:2 row ratio of Maize+Ricebean recorded the maximum plant height in all the growth stages in both the years as compared to all other intercropping treatments. The increase in the plant height might be due to the reason that Maize was sown early as compared to the component intercrop and which provides better opportunity for elongation of stem to compete and take up more of moisture, nutrients and other growth factors. The maximum LAl was reported in 2:2 paired row ratios of Maize and Soybean which showed increase till up to 90 DAS and then gradually decline or there was lesser increase in LAI as it reaches to maturity. The higher value of LAl at early growth stages was due to better growth and productivity of the crop. In a similar study, Alhaji (2008) found that intercropping of different varieties of cowpea with maize was significant in affecting the plant height, leaf area and leaf area indices of maize. Sole Maize performed better or reported maximum stem thickness as compared to other intercropping treatments. The result also corresponds with those of Kithan (2012); Yhokha (2015).

\subsection{Yield parameters}

Sole Maize recorded significantly higher values in regard to number of cobs plant ${ }^{-1}$ than all the different intercropping treatments. Introduction of intercrops in maize reduces the yield attributes of maize however, less reduction was noted in 2:1 row ratio of Maize+perilla as compared to other different intercropping treatments. It may be because of the reason that the peak demand periods of the 2 crops for light, nutrients and water were different and there was optimum utilization of physical resources (Table 2 and 3). This was in conformity with the findings by Padhi (2001) who reported that intercropping reduced the values of yield attributes and Kaushal et al. (2015) who did on maize (Zea mays)- based intercropping systems. The highest cob weight was recorded in Sole Maize with mean of $143.67 \mathrm{~g}, 144.67 \mathrm{~g}$ and pooled of $144.17 \mathrm{~g}$. Sole Maize with mean of $555.33,556.00$ and pooled of 555.67 recorded the maximum number of grains $\mathrm{cob}^{-1}$. Sole Maize with mean of $81 \%, 80.67 \%$ and pooled of $80.83 \%$ observed the highest shelling percentage. Significantly highest grain yield was obtained in Sole crop of Maize. Intercropping of maize with different intercrops resulted in statistically at par results with all treatments except at 1:2 row ratio of Maize+Ricebean which recorded the lowest grain yield (Table 4). A substantial reduction in grain yield of associated maize crop was observed as compared to maize alone. Khalil (1990) also reported reduction in grain yield of maize due to intercropping. The reduction in the grain yield might be due to spatial and temporal competition for growth factors for a prolonged period and their susceptibility to shading effect of maize crop. The results confirm the findings of Padhi and Panigrahi (2006); Kaushal et al. (2015) who did on maize (Zea mays)- based intercropping systems. Crop intensification with intercropping reduced the yield of main crop due to more interspecific competition (Singh et al., 2008) and disturbance of the habitat (Banik et al., 2000). This was also in conformity with the finding by Singh et al. 2015. 2:2 paired row ratio of Maize+soybean recorded the highest grain yield among all the different intercropping (Table 5). The reason for maximum grain yield in paired row planting may be due to decreased competition between plants because of equivalent spatial arrangement of plant. Similar finding was also reported by Maitra et al. (2000). This might be due to appropriate mutual co-operation for atmospheric nitrogen by leguminous plant in 2:2 rows. This result corresponds with the findings by Mahapatra and Pradhan (1992) whose intercropping was on maize and cowpea.Intercropping significantly affected grain 
Table 1: Effect of production potential of maize (Zea mays L.)- based intercropping systems on growth and yield of maize (pooled data of 2015 and 2016)

\begin{tabular}{|c|c|c|c|c|c|c|c|c|c|c|}
\hline \multirow[t]{2}{*}{ Treatment } & \multirow{2}{*}{$\begin{array}{l}\text { Plant } \\
\text { height } \\
\text { (cm) }\end{array}$} & \multirow{2}{*}{$\begin{array}{l}\text { Leaf area } \\
\text { index } \\
\text { (LAI) }\end{array}$} & \multirow{2}{*}{$\begin{array}{l}\text { No. of } \\
\text { cobs } \\
\text { plant }^{-1}\end{array}$} & \multirow{2}{*}{$\begin{array}{l}\text { Cob } \\
\text { weight } \\
\text { (g) }\end{array}$} & \multirow{2}{*}{$\begin{array}{l}\text { No. of } \\
\text { grains } \\
\text { cob }^{-1}\end{array}$} & \multirow{2}{*}{$\begin{array}{l}\text { Shelling } \\
\text { percent- } \\
\text { age (\%) }\end{array}$} & \multirow{2}{*}{$\begin{array}{c}\text { Grain } \\
\text { yield } \\
\left(\mathrm{kg} \mathrm{ha}^{-1}\right)\end{array}$} & \multirow{2}{*}{$\begin{array}{l}\text { Stover } \\
\text { yield } \\
\left(\mathrm{kg} \mathrm{ha}^{-1}\right)\end{array}$} & \multicolumn{2}{|c|}{ Harvest index (\%) } \\
\hline & & & & & & & & & 2015 & 2016 \\
\hline $\mathrm{T}_{1}$ & 315.25 & 2.23 & 1.92 & 144.17 & 555.67 & 80.83 & 4280.06 & 5296.82 & 44.87 & 44.52 \\
\hline$T_{2}$ & - & - & - & - & - & - & - & - & - & - \\
\hline $\mathrm{T}_{3}$ & - & - & - & - & - & - & - & - & - & - \\
\hline $\mathrm{T}_{4}$ & - & - & - & - & - & - & - & - & - & - \\
\hline$T_{5}$ & - & - & - & - & - & - & - & - & - & - \\
\hline$T_{6}$ & 323.29 & 2.05 & 1.68 & 118.83 & 489.67 & 72.17 & 3660.00 & 4810.67 & 43.38 & 43.04 \\
\hline $\mathrm{T}_{7}$ & 331.25 & 1.93 & 1.85 & 131.50 & 531.67 & 76.50 & 3952.33 & 5103.23 & 43.82 & 43.48 \\
\hline $\mathrm{T}_{8}$ & 317.96 & 1.82 & 1.57 & 115.83 & 400.33 & 66.50 & 3407.50 & 4586.50 & 42.96 & 42.30 \\
\hline $\mathrm{T}_{9}$ & 323.08 & 2.13 & 1.75 & 127.50 & 511.67 & 73.50 & 3859.17 & 5001.90 & 43.69 & 43.42 \\
\hline $\mathrm{T}_{10}$ & 322.29 & 2.13 & 1.65 & 123.17 & 430.33 & 67.50 & 3860.17 & 5011.05 & 43.69 & 43.34 \\
\hline $\mathrm{T}_{11}$ & 317.88 & 1.90 & 1.58 & 112.83 & 390.33 & 66.83 & 3390.50 & 4540.68 & 42.93 & 42.57 \\
\hline $\mathrm{T}_{12}$ & 329.29 & 2.28 & 1.83 & 131.50 & 500.33 & 76.50 & 3998.50 & 5149.49 & 43.88 & 43.54 \\
\hline $\mathrm{T}_{13}$ & 334.29 & 2.20 & 1.74 & 126.50 & 460.33 & 73.17 & 3846.50 & 4996.67 & 43.67 & 43.33 \\
\hline $\mathrm{T}_{14}$ & 325.79 & 2.26 & 1.73 & 133.83 & 473.00 & 67.17 & 3886.50 & 5036.88 & 43.73 & 43.38 \\
\hline $\mathrm{T}_{15}$ & 342.58 & 2.28 & 1.87 & 137.83 & 501.67 & 75.83 & 4045.17 & 5429.29 & 42.85 & 42.54 \\
\hline $\mathrm{T}_{16}$ & 309.33 & 2.08 & 1.58 & 113.17 & 336.33 & 68.50 & 3420.83 & 4630.25 & 42.23 & 42.73 \\
\hline $\mathrm{T}_{17}$ & 331.63 & 2.25 & 1.72 & 128.50 & 389.67 & 67.50 & 3728.00 & 4878.18 & 43.49 & 43.14 \\
\hline $\mathrm{T}_{18}$ & 335.29 & 2.23 & 1.73 & 128.83 & 466.33 & 78.17 & 3779.67 & 4930.15 & 43.57 & 43.22 \\
\hline $\mathrm{T}_{19}$ & 324.00 & 2.12 & 1.68 & 121.17 & 433.00 & 72.83 & 3517.17 & 4667.51 & 43.15 & 42.80 \\
\hline $\mathrm{T}_{20}$ & 310.83 & 2.12 & 1.65 & 115.17 & 359.67 & 70.83 & 3162.17 & 4312.52 & 42.49 & 42.13 \\
\hline $\mathrm{T}_{21}$ & 339.92 & 2.52 & 1.87 & 138.17 & 497.00 & 78.83 & 3987.83 & 5138.05 & 44.25 & 43.93 \\
\hline SEm \pm & 4.69 & 0.05 & 0.02 & 1.71 & 8.60 & 1.27 & 126.60 & 113.88 & & \\
\hline $\mathrm{CD}(p=0.05)$ & 13.24 & 0.14 & 0.06 & 4.84 & 24.29 & 3.60 & 357.67 & 321.72 & & \\
\hline
\end{tabular}

$T_{1}$ : Sole maize; $T_{2}$ : Sole perilla; $T_{3}$ : Sole sesame; $T_{4}$ : Sole ricebean; $T_{5}$ : Sole soybean; $T_{6}:$ Maize+perilla $(1: 1) ; T_{7}$ : Maize+perilla (1:2); $\mathrm{T}_{8}$ : Maize +perilla (2:1); $\mathrm{T}_{9}$ : Maize +Perilla (2:2); $\mathrm{T}_{10}$ : Maize+sesame (1:1); $\mathrm{T}_{11}$ : Maize+sesame (1:2); $\mathrm{T}_{12}$ : Maize+sesame (2:1); $T_{13}$ : Maize+sesame (2:2); $T_{14}$ : Maize+ricebean (1:1); $T_{15}:$ Maize+ricebean (1:2); $T_{16}$ : Maize+ricebean (2:1); $T_{17}:$ Maize tricebean (2:2); $\mathrm{T}_{18}$ : Maize+soybean (1:1); $\mathrm{T}_{19}:$ Maize+soybean (1:2); $\mathrm{T}_{20}$ : Maize+soybean (2:1); $\mathrm{T}_{21}$ : Maize+soybean (2:2)

Table 2: Effect of production potential of maize (Zea mays L.)- based intercropping systems on growth and yield of perilla (pooled data of 2015 \& 2016)

\begin{tabular}{lcccccccccc}
\hline Treatment & PH & LAI & NPBP & NCP & $\begin{array}{c}\text { No.of seeds } \\
\text { capsule }\end{array}$ & $\begin{array}{c}\text { Test weight } \\
(\mathrm{g})\end{array}$ & $\begin{array}{c}\text { Seed yield } \\
\left(\mathrm{kg} \mathrm{ha}^{-1}\right)\end{array}$ & $\begin{array}{c}\text { Stover yield } \\
\left(\mathrm{kg} \mathrm{ha}^{-1}\right)\end{array}$ & \multicolumn{2}{c}{ Harvest index (\%) } \\
\hline $\mathrm{T}_{2}$ & 118.29 & 1.98 & 10.38 & 149.08 & 39.08 & 2.25 & 891.58 & 1481.48 & 37.77 & 37.38 \\
$\mathrm{~T}_{6}$ & 112.25 & 1.90 & 8.71 & 142.50 & 34.75 & 2.14 & 643.15 & 1165.95 & 35.74 & 35.36 \\
$\mathrm{~T}_{7}$ & 116.33 & 1.95 & 9.54 & 146.17 & 37.75 & 2.18 & 716.74 & 1246.75 & 36.69 & 36.32 \\
$\mathrm{~T}_{8}$ & 108.92 & 1.88 & 8.13 & 141.17 & 34.42 & 2.14 & 552.24 & 1090.91 & 33.80 & 33.41 \\
$\mathrm{~T}_{9}$ & 114.75 & 1.94 & 9.29 & 144.58 & 36.08 & 2.15 & 676.33 & 1206.35 & 36.11 & 35.74 \\
$\mathrm{SEm} \pm$ & 0.31 & 0.00 & 0.08 & 0.31 & 0.32 & 0.02 & 13.65 & 12.91 & & \\
$\mathrm{CD}(p=0.05)$ & 0.92 & 0.01 & 0.24 & 0.94 & 0.95 & NS & 40.93 & 38.72 & & \\
\hline
\end{tabular}

PH: Plant height (cm); LAl: Leaf area index; NPBP: No. of primaary branches plant ${ }^{-1}$; NCP: No. of capsules plant ${ }^{-1}$ 
Table 3: Effect of production potential of maize (Zea mays L.)- based intercropping systems on growth and yield of sesame (pooled data of 2015 and 2016)

\begin{tabular}{lcccccccccc}
\hline Treatment & PH & LAI & NPBP & NCP & $\begin{array}{c}\text { No.of seeds } \\
\text { capsule }\end{array}$ & $\begin{array}{c}\text { Test weight } \\
\text { (g) }\end{array}$ & $\begin{array}{c}\text { Seed yield } \\
\left(\mathrm{kg} \mathrm{ha}^{-1}\right)\end{array}$ & $\begin{array}{c}\text { Stover yield } \\
\left(\mathrm{kg} \mathrm{ha}^{-1}\right)\end{array}$ & $\begin{array}{c}\text { Harvest index (\%) } \\
2015\end{array}$ & 2016 \\
\hline $\mathrm{T}_{3}$ & 208.17 & 1.51 & 16.30 & 189.50 & 23.33 & 2.27 & 1552.19 & 2161.62 & 41.84 & 41.84 \\
$\mathrm{~T}_{10}$ & 191.83 & 1.24 & 12.30 & 166.83 & 22.17 & 2.18 & 1165.95 & 1473.30 & 44.25 & 44.25 \\
$\mathrm{~T}_{11}$ & 186.17 & 1.13 & 11.30 & 159.33 & 22.33 & 2.18 & 950.88 & 1359.31 & 41.26 & 41.26 \\
$\mathrm{~T}_{12}$ & 199.17 & 1.32 & 14.97 & 183.17 & 22.54 & 2.27 & 1310.24 & 1730.16 & 42.95 & 42.95 \\
$\mathrm{~T}_{13}$ & 196.83 & 1.35 & 13.63 & 177.00 & 22.17 & 2.20 & 1220.71 & 1567.10 & 43.82 & 43.82 \\
$\mathrm{SEm} \pm$ & 1.49 & 0.02 & 0.34 & 4.37 & 0.90 & 0.02 & 7.83 & 51.89 & 155.58 \\
$\mathrm{CD}(p=0.05)$ & 4.47 & 0.05 & 1.02 & 13.10 & $\mathrm{NS}$ & $\mathrm{NS}$ & 23.47 & & \\
\hline
\end{tabular}

Table 4: Effect of production potential of maize (Zea mays L.)- based intercropping systems on growth and yield of ricebean (pooled data of 2015 and 2016)

\begin{tabular}{|c|c|c|c|c|c|c|c|}
\hline \multirow[t]{2}{*}{ Treatment } & \multirow{2}{*}{$\begin{array}{l}\text { Plant height } \\
(\mathrm{cm})\end{array}$} & \multirow{2}{*}{$\begin{array}{l}\text { No. of pods } \\
\text { plant }^{-1}\end{array}$} & \multirow{2}{*}{$\begin{array}{l}\text { No. of seeds } \\
\text { pod }^{-1}\end{array}$} & \multirow{2}{*}{$\begin{array}{l}\text { Seed yield } \\
\left(\mathrm{kg} \mathrm{ha}^{-1}\right)\end{array}$} & \multirow{2}{*}{$\begin{array}{l}\text { Stover yield } \\
\qquad\left(\mathrm{kg} \mathrm{ha}^{-1}\right)\end{array}$} & \multicolumn{2}{|c|}{ Harvest index (\%) } \\
\hline & & & & & & 2015 & 2016 \\
\hline $\mathrm{T}_{3}$ & 148.58 & 125.67 & 8.73 & 1510.10 & 1718.85 & 46.76 & 46.78 \\
\hline $\mathrm{T}_{10}$ & 144.92 & 117.33 & 8.03 & 1152.96 & 1330.45 & 46.49 & 46.36 \\
\hline $\mathrm{T}_{11}$ & 146.58 & 122.67 & 8.57 & 1225.11 & 1398.27 & 46.69 & 46.71 \\
\hline $\mathrm{T}_{12}$ & 141.33 & 107.33 & 7.22 & 989.90 & 1177.49 & 45.82 & 45.53 \\
\hline $\mathrm{T}_{13}$ & 143.83 & 112.00 & 7.50 & 1124.10 & 1303.03 & 46.30 & 46.33 \\
\hline SEm \pm & 0.31 & 1.39 & 0.15 & 12.25 & 12.12 & & \\
\hline $\operatorname{CD}(p=0.05)$ & 0.94 & 4.16 & 0.44 & 36.73 & 36.34 & & \\
\hline
\end{tabular}

Table 5: Effect of production potential of maize (Zea mays L.)- based intercropping systems on growth of soybean (pooled data of 2015 and 2016)

\begin{tabular}{|c|c|c|c|c|c|c|c|c|c|c|}
\hline \multirow[t]{2}{*}{ Treatment } & \multirow[t]{2}{*}{$\mathrm{PH}$} & \multirow[t]{2}{*}{ NPBP } & \multirow[t]{2}{*}{ NRNP } & \multirow[t]{2}{*}{ NPP } & \multirow[t]{2}{*}{ NSP } & \multirow{2}{*}{$\begin{array}{c}\text { Test weight } \\
\text { (g) }\end{array}$} & \multirow{2}{*}{$\begin{array}{l}\text { Seed yield } \\
\left(\mathrm{kg} \mathrm{ha}^{-1}\right)\end{array}$} & \multirow{2}{*}{$\begin{array}{l}\text { Stover yield } \\
\qquad\left(\mathrm{kg} \mathrm{ha}^{-1}\right)\end{array}$} & \multicolumn{2}{|c|}{ Harvest index (\%) } \\
\hline & & & & & & & & & 2015 & 2016 \\
\hline $\mathrm{T}_{3}$ & 96.67 & 10.34 & 24.50 & 52.58 & 3.73 & 35.22 & 1840.07 & 2917.51 & 38.61 & 38.74 \\
\hline $\mathrm{T}_{10}$ & 90.33 & 10.11 & 21.50 & 47.92 & 3.15 & 33.08 & 1519.48 & 2326.12 & 39.46 & 39.56 \\
\hline $\mathrm{T}_{11}$ & 87.33 & 9.94 & 20.58 & 45.03 & 3.13 & 32.98 & 1461.76 & 2268.40 & 39.13 & 39.24 \\
\hline $\mathrm{T}_{12}$ & 83.83 & 9.79 & 20.33 & 44.58 & 3.11 & 33.29 & 1421.35 & 2147.18 & 39.77 & 39.89 \\
\hline $\mathrm{T}_{13}$ & 94.67 & 10.24 & 22.83 & 51.17 & 3.44 & 33.72 & 1565.65 & 2398.27 & 39.45 & 39.55 \\
\hline SEm \pm & 1.54 & 0.21 & 0.17 & 1.20 & 0.11 & 0.42 & 11.89 & 26.44 & & \\
\hline $\operatorname{CD}(p=0.05)$ & 4.60 & NS & 0.51 & 3.61 & NS & NS & 35.66 & 79.28 & & \\
\hline
\end{tabular}

NRNP: Number of root nodules plant ${ }^{-1}$; NPP: No. of pods plant ${ }^{-1}$; NSP: No. of seeds pod ${ }^{-1}$

yield of maize crop. Intercropped maize provided slightly lower grain yield than sole cropping on mean basis. This decline in the grain yield despite similar plant population in sole and intercropped stand may be attributed to change in the planting pattern, which induced more inter-species and intra-species competition in the intercropped stand, both underground and above-ground (Jain et al., 2015).

\subsection{Biological efficiencies}

The highest LER value was obtained from 2:2 paired row ratio of Maize+soybean. This finding was in accordance with Mahapatra and Pradhan (1992) who observed in intercropping on maize and soybean and Khan-zada et al. (1992). 2:2 paired row ratio of Maize+Soybean recorded the maximum RCC as compared to all other different intercropping treatments. The products of the relative crowding coefficient $\left(\mathrm{K}_{\text {total }}\right)$ were always more than unity (1) indicating a definite yield advantage due to intercropping. It can be inferred that the intercropped maize utilized the resources more efficiently than its associated 
crops which appeared to be dominated. The highest RCC value of the product of the coefficient was also recorded by Sheoran et al. (2009) when maize was intercropped with greengram and also by Singhe et al. (2015). Intercropping at 2:2 paired rows of Maize+soybean gave significantly higher maize equivalent yield as compared to other intercropping treatments. The lowest maize equivalent yield was recorded in 2:1 row ration of Maize+Perilla. The reason might be due to the significant reduction in seed yield of perilla as compared to the other intercrop treatments Mandal et al. (2014) also reported similar results (Table 6 and 7). The intercropping at 2:2 paired row ratio of Maize+Soybean recorded the maximum with regard to ATER. The area time equivalent ratio (ATER) provides more a realistic comparision of the yield advantage of intercropping over that of sole cropping than LER as it considers variation in time taken by the component crops of different intercropping systems. Regarding the planting patterns, the ATER values for maize-legume intercropping were higher than maize-perilla intercropping indicating a better bio-economic efficiency of soybean intercropping in

Table 6: Effect of production potential of maize (Zea mays L.)- Based intercropping systems on biological efficiencies

\begin{tabular}{lcccccc}
\hline Treat- & \multicolumn{6}{c}{ ment } \\
\cline { 2 - 7 } & \multicolumn{2}{c}{ LER } & \multicolumn{3}{c}{$\mathrm{RCC}$} & \multicolumn{3}{c}{ CEY $\left(\mathrm{kg} \mathrm{ha}^{-1}\right)$} \\
\cline { 2 - 7 } & 2015 & 2016 & 2015 & 2016 & 2015 & 2016 \\
\hline $\mathrm{T}_{1}$ & 1 & 1 & 1 & 1 & 1 & 1 \\
$\mathrm{~T}_{2}$ & 1 & 1 & 1 & 1 & 1 & 1 \\
$\mathrm{~T}_{3}$ & 1 & 1 & 1 & 1 & 1 & 1 \\
$\mathrm{~T}_{4}$ & 1 & 1 & 1 & 1 & 1 & 1 \\
$\mathrm{~T}_{5}$ & 1 & 1 & 1 & 1 & 1 & 1 \\
$\mathrm{~T}_{6}$ & 1.57 & 1.58 & 5.81 & 5.99 & 1926.39 & 1932.48 \\
$\mathrm{~T}_{7}$ & 1.72 & 1.72 & 23.79 & 24.42 & 2147.19 & 2153.25 \\
$\mathrm{~T}_{8}$ & 1.41 & 1.42 & 7.69 & 7.93 & 1653.69 & 1659.72 \\
$\mathrm{~T}_{9}$ & 1.66 & 1.66 & 36.19 & 37.16 & 2025.96 & 2032.02 \\
$\mathrm{~T}_{10}$ & 1.65 & 1.65 & 9.07 & 9.31 & 3532.47 & 3463.2 \\
$\mathrm{~T}_{11}$ & 1.4 & 1.4 & 7.51 & 7.74 & 2883.12 & 2822.16 \\
$\mathrm{~T}_{12}$ & 1.77 & 1.77 & 28.03 & 28.77 & 3956.7 & 3904.77 \\
$\mathrm{~T}_{13}$ & 1.69 & 1.69 & 35.05 & 17.96 & 3687.6 & 3636.69 \\
$\mathrm{~T}_{14}$ & 1.67 & 1.67 & 9.75 & 10 & 3445.89 & 3471.87 \\
$\mathrm{~T}_{15}$ & 1.75 & 1.75 & 34.10 & 34.78 & 3662.34 & 3688.32 \\
$\mathrm{~T}_{16}$ & 1.43 & 1.47 & 7.21 & 8.82 & 2943.72 & 2995.65 \\
$\mathrm{~T}_{17}$ & 1.61 & 1.61 & 13.33 & 13.68 & 3359.31 & 3385.29 \\
$\mathrm{~T}_{18}$ & 1.7 & 1.7 & 7.46 & 7.65 & 4554.12 & 4562.76 \\
$\mathrm{~T}_{19}$ & 1.61 & 1.61 & 9.54 & 9.35 & 4380.96 & 4389.6 \\
$\mathrm{~T}_{20}$ & 1.5 & 1.51 & 2.78 & 5.74 & 4259.73 & 4268.4 \\
$\mathrm{~T}_{21}$ & 1.78 & 1.78 & 53.95 & 55.22 & 4692.63 & 4701.3 \\
\hline & & & & & &
\end{tabular}

Table 7: Effect of production potential of maize (Zea mays L.)- based intercropping systems on biological efficiencies

\begin{tabular}{lcccccc}
\hline Treat- & \multicolumn{6}{c}{ Biological efficiencies } \\
\cline { 2 - 7 } & \multicolumn{2}{c}{ ATER } & \multicolumn{3}{c}{ Aggressivity (\%) } & \multicolumn{3}{c}{ SPI } \\
\cline { 2 - 7 } & 2015 & 2016 & 2015 & 2016 & 2015 & 2016 \\
\hline $\mathrm{T}_{1}$ & 1 & 1 & 1 & 1 & 1 & 1 \\
$\mathrm{~T}_{2}$ & 1 & 1 & 1 & 1 & 1 & 1 \\
$\mathrm{~T}_{3}$ & 1 & 1 & 1 & 1 & 1 & 1 \\
$\mathrm{~T}_{4}$ & 1 & 1 & 1 & 1 & 1 & 1 \\
$\mathrm{~T}_{5}$ & 1 & 1 & 1 & 1 & 1 & 1 \\
$\mathrm{~T}_{6}$ & 1.25 & 1.26 & 0.132 & 0.135 & 66.60 & 68.36 \\
$\mathrm{~T}_{7}$ & 1.38 & 1.39 & 0.52 & 0.522 & 73.02 & 74.83 \\
$\mathrm{~T}_{8}$ & 1.12 & 1.13 & -0.22 & -0.221 & 59.76 & 61.41 \\
$\mathrm{~T}_{9}$ & 1.33 & 1.33 & 0.071 & 0.072 & 70.17 & 71.94 \\
$\mathrm{~T}_{10}$ & 1.37 & 1.43 & 0.15 & 0.155 & 70 & 71.43 \\
$\mathrm{~T}_{11}$ & 1.15 & 1.20 & 0.48 & 0.49 & 59.45 & 60.75 \\
$\mathrm{~T}_{12}$ & 1.47 & 1.53 & -0.37 & -0.38 & 75.22 & 76.93 \\
$\mathrm{~T}_{13}$ & 1.40 & 1.46 & 0.056 & 0.057 & 71.28 & 72.90 \\
$\mathrm{~T}_{14}$ & 1.50 & 1.44 & 0.144 & 0.145 & 70.64 & 72.46 \\
$\mathrm{~T}_{15}$ & 1.56 & 1.5 & 0.54 & 0.54 & 74.26 & 76.11 \\
$\mathrm{~T}_{16}$ & 1.29 & 1.27 & -0.26 & -0.25 & 60.69 & 63.86 \\
$\mathrm{~T}_{17}$ & 1.44 & 1.39 & 0.063 & 0.064 & 68.24 & 70.05 \\
$\mathrm{~T}_{18}$ & 1.45 & 1.45 & 0.056 & 0.058 & 72.21 & 74.03 \\
$\mathrm{~T}_{19}$ & 1.39 & 1.39 & 0.42 & 0.427 & 68.26 & 70.05 \\
$\mathrm{~T}_{20}$ & 1.29 & 1.29 & -0.404 & -0.401 & 63.78 & 65.55 \\
$\mathrm{~T}_{21}$ & 1.53 & 1.53 & 0.04 & 0.041 & 75.36 & 77.20 \\
\hline & & & 1 & \\
\hline
\end{tabular}

maize over that of perilla intercropping. Higher values of ATER in intercropped treatments compared with monoculture of maize were attributed to efficient utilization of natural (land, light and rainfall). Higher ATER values have also been reported in maize+blackgram (Padhi and Panigrahi, 2006); Singh et al. (2015) associations compared with monoculture of their component crops .

Aggressivity value was the minimum for 2:2 paired row ratios which indicated that soybean was the most competitive crop to maize. The results are in line with the findings of Ehsanullah et al. (2011); Takim (2012); Yilmaz et al. (2008) who reported the dominant effect of maize having a positive " $A$ " value when grown in association with legumes. The results are also in conformity with those of Sarkar et al. (2003); Singh et al. (2015). The Aggressivity of soybean was negative thus it is considered as the less dominant crop in the system. The results was in conformity with the findings by Sawargaonkar et al., 2008 who did on the performance of Kharif maize based legumes intercropping systems.

\subsection{Economics}

The data on gross return revealed that it was highest in all 
the intercropping as compared to their respective sole crop treatments. This may be attributed to higher total yield of the component crops over the sole crop. Maize and Soybean at 2:2 paired row ratio recorded the highest gross return which can be attributed to the higher seed yield of soybean. The highest net return among the different intercropping treatments was recorded in 2:2 paired row ratios of Maize+soybean. The results are in close conformity with the findings of Shivay et al. (2001); Padhi and Panigrahi (2006); Kaushal et al. (2015). Similar finding was reported by Panwar et al. (2016) on beneficial of paired row ratios. The data revealed that 2:2 paired row ratio of Maize+soybean gave maximum $\mathrm{B}: \mathrm{C}$ ratio which might be due to the highest net return. Similar finding was reported by Panwar et al. (2016); Kithan (2012) on beneficial of paired row ratios (Table 8 ).

\begin{tabular}{|c|c|c|c|c|c|c|}
\hline \multirow[t]{3}{*}{ Treatment } & \multicolumn{6}{|c|}{ Economics } \\
\hline & \multicolumn{2}{|c|}{ LERa Gross return (₹ ha-1) } & \multicolumn{2}{|c|}{ Net return $\left(₹ \mathrm{ha}^{-1}\right)$} & \multicolumn{2}{|c|}{ Benefit cost ratio $(B: C)$} \\
\hline & 2015 & 2016 & 2015 & 2016 & 2015 & 2016 \\
\hline $\mathrm{T}_{1}$ & 84600 & 86602.4 & 60100 & 62102.4 & 2.45 & 2.53 \\
\hline $\mathrm{T}_{2}$ & 53454.6 & 53535.6 & 32454.6 & 32535.6 & 1.54 & 1.55 \\
\hline $\mathrm{T}_{3}$ & 93737.4 & 92525.4 & 71891.4 & 70679.4 & 3.29 & 3.23 \\
\hline $\mathrm{T}_{4}$ & 90303 & 90909 & 68968 & 69574 & 3.23 & 3.26 \\
\hline $\mathrm{T}_{5}$ & 110302.8 & 110505 & 86302.8 & 86505 & 3.59 & 3.60 \\
\hline $\mathrm{T}_{6}$ & 110721.2 & 112856.2 & 81721.2 & 83856.2 & 2.82 & 2.89 \\
\hline $\mathrm{T}_{7}$ & 120990.4 & 123111.6 & 90990.4 & 93111.6 & 3.03 & 3.10 \\
\hline$T_{8}$ & 100220.4 & 102347.8 & 71220.4 & 73347.8 & 2.45 & 2.53 \\
\hline $\mathrm{T}_{9}$ & 116699.2 & 118827 & 86699.2 & 88827 & 2.89 & 2.96 \\
\hline $\mathrm{T}_{10}$ & 146849.4 & 147470.6 & 117003.4 & 117624.6 & 3.92 & 3.94 \\
\hline $\mathrm{T}_{11}$ & 124469 & 125256.6 & 93469 & 94256.6 & 3.01 & 3.04 \\
\hline $\mathrm{T}_{12}$ & 158100.6 & 159068.8 & 128254.6 & 129222.8 & 4.30 & 4.33 \\
\hline $\mathrm{T}_{13}$ & 149685.4 & 150660.4 & 118685.4 & 119660.4 & 3.83 & 3.86 \\
\hline $\mathrm{T}_{14}$ & 145651.2 & 148164 & 116316.2 & 118829 & 3.96 & 4.05 \\
\hline $\mathrm{T}_{15}$ & 153160.2 & 155659.8 & 123160.2 & 125659.8 & 4.10 & 4.19 \\
\hline $\mathrm{T}_{16}$ & 125107.8 & 130513 & 95772.8 & 101178 & 3.26 & 3.45 \\
\hline$T_{17}$ & 140746.2 & 143265.8 & 110746.2 & 113265.8 & 3.69 & 3.77 \\
\hline $\mathrm{T}_{18}$ & 165682.4 & 167841.8 & 136682.4 & 138841.8 & 4.71 & 4.79 \\
\hline $\mathrm{T}_{19}$ & 156965.8 & 159132 & 126965.8 & 129132 & 4.23 & 4.30 \\
\hline $\mathrm{T}_{20}$ & 147441.2 & 149608 & 118441.2 & 120608 & 4.08 & 4.16 \\
\hline $\mathrm{T}_{21}$ & 172612.6 & 174779.4 & 142612.6 & 144779.4 & 4.75 & 4.82 \\
\hline
\end{tabular}

\section{Conclusion}

Based on the findings from 2 (Two) years of experimentation, the study can be concluded that 2:2 Paired row ratios of Maize+soybean proved the best option viewing yield advantages, optimum exploitation of the environmental resources, production efficiencies and monetary values. Inclusion of legumes (especially soybean) in the maize culture system can be a very useful management strategy not only to meet out the food requirements but also to increase profitability for farmers, sustainability of agriculture and conservation of soil health.

\section{References}

Ahmed, Z., Ashiq, R., 1992. Genetic variability and correlation studies in ricebean. Journal of Agricultural Research13: 121-125.

Alhaji, I.H., 2008. Yield performance of some cowpea varieties under sole and intercropping with maize at Bauchi, Nigeria. African Research Review 2(3), 278-291.

Anonymous, 2014. District wise Achievement of Area, Production and Yield for the year 2012-2013 in respect of Nagaland State. Directorate of Agriculture, Nagaland, Kohima, 1-7.

Banik, P., Sasmal, T., Ghosal, P.K., Bagchi, D.K., 2000. Evaluation 
of mustard (Brassica compestris var. Toria) and legume intercropping under 1:1 and 2:1 row-replacement series systems. Journal of Agronomy and Crop Science 185, 9-14.

DACNET, 2014. Directorate of Economics and Statistics, DAC, Ministry of Agriculture, Government of India, New Delhi.http://eands.dacnet.nic.in/StateData_12-13Year. htm.

Ehsanulla, M.J., Ahmad, R., Tariq, A., 2011. Bio-economic assessment of maize-mash intercropping system. Crop and Environment 2, 41-46.

Jain, N.K., Singh, H., Dashora, L.N., Mundra, S.L., 2015. Maize (Zea mays)-wheat (Triticum aestivum) cropping system: Intensification through introduction of pulses. Indian Journal of Agronomy 60(3), 347-351.

Kaushal S., Rameshwar S., Punam, J.P., Sankhyan, N.K., 2015. Performance of maize (Zea mays)-based intercropping systems and their residual effect on wheat (Triticuma estivum)+lentil (Lens culinaris) intercropping system under organic conditions. Indian Journal of Agronomy 60(2), 224-229.

Khalil, A., 1990. Studies on biological intercrop relationship and water use techniques in wheat. Ph.D. Thesis, dept. of Agronomy, University Agri. Faisalabad.

Khan-zada, Saeed-Ahmed, Zada, K., Ahmad, S., 1992. Biologic and intercrop studies on yield and nitrogen fixation of soybean and maize. Sarhad Journal of Agriculture 8, 613-622.

Kithan, L., 2012. Effect of maize (Zea mays L.) and soybean (Glycine max L. Merrill) intercropping on weed dynamics. M.Sc (Ag.) Thesis, Nagaland University, Medziphema.

Mahapatra, B.K., Pradhan, L., 1992. Intercropping fodder legumes with maize in different planting patterns. Annuals of Agriculture Research 13(4), 366-371.

Maitra, S., Ghosh, D.C., Soundra, G., Jana, P.K., Roy, D.K., 2000. Productivity, competition and economics of intercropping legumes in fingermillets (Eleusine corocana) at different fertility levels. Indian Journal of Agricultural Sciences 70(12), 824-28.

Mandal, M.K., Banerjee, M., Banerjee, H., Alipatra, A., Malik G.C., 2014. Productivity of maize (Zea mays L.) based intercropping system during kharif season under red and lateritic tracts of West Bengal. The Bioscan 9(1), 31-35.

Padhi, A.K., Panigrahi, R.K., 2006. Effect of intercrop and crop geometry on productivity, economics, energetics and soil fertility status of maize (Zea mays) -based intercropping systems. Indian Journal of Agronomy 51(3), 174-177.
Padhi, A.K., 2001. Effect of vegetable intercropping on productivity, economics and energetic of maize (Zea mays). Indian Journal of Agronomy 46(2), 204-210.

Panwar C.S., Singh, J.P., Meena, R.N., Kumar P., 2016. Effect of planting pattern and fertility level on hybrid maize (Zea mays)+legume intercropping system under dryland condition. Indian Journal of Agronomy 61(1), 20-24.

Sarkar, R.K., Malik, G.C., Goswami, S., 2003. Productivity potential and economic feasibility of sesame (Sesamum indicum)-based intercropping system with different planting patterns on rainfed upland. Indian Journal of Agronomy 48(3), 164-167.

Sawargaonkar, G.L., Shelke, D.K., Shinde, S.A., Kshirsagar, S., 2008. Performance of kharif maize based legumes intercropping systems under different fertilizer doses. International Journal of Agricultural Sciences 4(1), 152-155.

Sheoran, P., Sardana, V., Singh, S., Singh, S., 2009. Productivity potential and economic feasibility of maize (Zea mays)greengram (Vigna radiata) intercropping system under rainfed conditions. Indian Journal of Agricultural Sciences 79, 535-7.

Shivay, Y.S., Singh, R.P., Pal, M., 2001. Productivity and economics of maize as influenced by intercropping with legumes and nitrogen levels. Annals of Agricultural Research New Series 22(4), 576-582.

Singh, U., Saad, A.A., Hasan, B., Singh, P., Singh, S.R., 2008. Production potential and economics of intercropping of lentil (Lens culinaris) with brown sarson (Brassica compestris) and oat (Avena sativa). Indian Journal of Agronomy 53, 135-139.

Singh, S., Bawa, S.S., Singh, S., Sharma, S.C., 2015. Evaluation of maize (Zea mays L.) based intercropping for productivity, resource-use efficiency and competition indices in the rainfed foothills of northwest Himalayas. Indian Journal of Agricultural Sciences 85(5), 614-621.

Takim, F.O., 2012. Advantages of maize-cowpea intercropping over sole cropping through competition indices. Journal of Agriculture and Biodiversity Research 1, 53-59.

Yhokha, K., 2015. Study of Soybean (Glycine max L. Merrill) based intercropping on weed dynamics. M.Sc. (Ag.) Thesis, Nagaland University, Medziphema.

Yilmaz, F., Atak, M., Erayman, M., 2008. Identification of advantages of maize-legume intercropping over solitary cropping through competition indices in the East Mediterranean region. Turkish Journal of Agriculture and Forestry 32, 111-119. 